\title{
An Enhancement of Human Relation Integrating Buddhist Principles for Administrators of Primary Schools in Thailand
}

\author{
Phrakrukosolpariyattayanukij (Tharueti Rungchaiwitoon) ${ }^{\mathbf{1}}$, Phrasuwanmahaphuthaphibal (Ho \\ Subhaddo) ${ }^{2}$, Phrakrusoponpattaravet (Ittipol Padhaniko) ${ }^{3}$, Lampong Klomkul ${ }^{4}$ \\ 1,2,3,4 Faculty of Education, Mahachulalongkornrajavidyalaya University \\ ${ }^{1}$ konkuandee@gmail.com, ${ }^{2}$ howattrimitr@gmail.com, ${ }^{3}$ oodwatsaymai@gmail.com, ${ }^{4}$ research.mcu@gmail.com
}

\begin{abstract}
The purpose of the research article was to propose the enhancement of human relation integrating Buddhist principles for administrators of primary schools in Thailand. Mixed methods research was used for research design. Questionnaires was used for data collection from 390 administrators and teachers in primary schools. Interview form was designed for interviewing 24 key informants, including focus group discussion with 9 experts. Qualitative data was analyzed by using content analysis whereas descriptive statistics was used to analyze quantitative data analysis. Results indicated that the enhancement of human relation integrating Buddhist principles for administrators of primary schools in Thailand can be developed through 3 aspects consisting of 1) personal characteristics, 2) understanding others, and 3) working with others, and analysis results showed at a high level in all aspects. For the integrating of human relations with Buddhist principles for administrators in primary schools in Thailand composed of 1) the principles of human relations for school administrators. In communication, both formal and informal between the school administrators and teachers, students and the community in order to work together to achieve the objectives divided into 3 areas which were (1) personal characteristics, (2) understanding of others, and (3) working with other. 2) Buddhist principles used in school administration, it is the Buddhist Dhamma principle which is integrated with human relations principles, consisting of 7 things which are (1) Kalyanmittita, (2) Yonisomanasikara, (3) Gracing virtues II, (4) Honesty III, (5) Secular Theology IV, (6) Sangahavatthu IV, and (7) Sappurisadhamma VII. The guidelines for the enhancement of human relation integrating Buddhist principles for administrators of primary schools in Thailand focused on 3 aspects: 1) Principles of human relations, 2) Buddhist principles used in school administration, 3) principles of school administration. The operation enhancement can be divided into 4 aspects of the school, which were (1) academic administration, (2) budget administration, (3) human resource management, and (4) general administration. The body of knowledge from this research can be divided into 3 areas as follows: Personal characteristics by integrating Buddhist principles. In understanding others is to be able to integrate with the Buddhist principles in 3 topics which are Kanlayanamitta, Yonisomanasikara and Gracing virtues II. In working with others is able to integrate with the Buddhist principles with 2 principles which are Gharavasa Dhamma IV and Sangahavatthu IV.
\end{abstract}

Keywords

Human Relation, Buddhist Principles, Primary Schools Administrators

Article Received: 10 August 2020, Revised: 25 October 2020, Accepted: 18 November 2020

\section{Introduction}

When humans are social animals that must interact with each other having to live together including friends, school friends, playmates, colleagues, and family members in the community, society, nation organization, there is a need to use human relations as a bridge for good relations with each other. Processes in human relations expressed in the form of motivation or create satisfaction according to the principle of human relations is important to every step of administration. Political organization is good, government agencies are good, business work, companies or industrial affairs as well as various associations will progress and proceeded to achieve the objectives partly depends on the talent of the management or supervisor in research planning or management. That is as follows: because human relations is a tool to create generosity and works. How smoothly the work can be performed depends on the integration of human relations with Buddhism well and correctly. This is because good interpersonal relations will help promote work with the group to have unity and unity. If the group loses good human relations, both vertically and horizontally on the chain of command. There will only be quarrels and confusion causing the group or organization to work to achieve results well. There is also no happiness in which to join in building faith in the work to happen.
Management is responsible for everything in the organization especially for the educational administration that will satisfy everyone, it is impossible to maintain kindness, and do not dare to argue that it will reduce the efficiency of the work. Therefore, executives must know how to use human relations in the administration with sincerity and seriousness in the work, have discretion in making decisions in the administration to ensure smoothness, reduce conflicts and has high efficiency. Qualifications in interpersonal relationships is therefore important to all types of people and all positions of educational administration at the heart of this quality lies in the respect, dignity and well-being of a person a good attribute of an executive should be characterized by a good talk. It is an encouragement to everyone congratulate and give colleagues opportunities to be successful empathize with others, create the best, livable and happiest images of work for everyone. There is a sense of ownership of the place together, eliminate conflicts and know how to control one's emotions to find a way to achieve cooperation the faith of all personnel. Therefore, executives must build human relations and need to know and understand themselves well. Because knowing oneself will make us understand who we are as a person, knowledge, ability, social status, values, dignity, needs and mind, what's virtue, what's bad, knowing ourselves will enable us to behave properly and accept the 
truth in what makes up ourselves as a guide for us to accept and understand more people as well. Executives who desire success in management must have good interpersonal relationships with all colleagues. The knowledge and competence of the executives alone will have only 20-30 percent of the success of the work, but if the group has good interpersonal skills, it will increase the efficiency of the performance of 80-90 percent. In school administration, it is important for the school administrators and worker since it is a management tool to help build good relationships achieving an understanding of trust that helps smooth operations effectively coordinate to achieve school goals to operate in accordance with the goals that have been set to be successful inevitably depends on colleagues Because administrators have to work with teachers, in order to work successfully. Human relations are also very important because some of them are capable and knowledgeable. Difficult results even though the management has a lot of knowledge but without good human relations with teachers. It is believed that the management does not achieve its objectives (Wirayut Chatakan, 2009: 37) [1].

In the school administration, administrators need to have a good understanding of interpersonal and interpersonal skills because the management has to work with many types of people Executives must have good personal qualities. To understand oneself through self-study at the same time, it must be studied in order to understand others and able to work with others (Rattikorn Chongwisarn, 2008: 190) [2]. To use only power in administration, it is not, it will cause problems and great difficulties. On the other hand, Executives with poor personal attributes don't understand others and unable to work with others will not be able to manage the school to run well or achieve the objectives set. Therefore, administrators should have a lot of human relations with teachers because it will cause cooperation and cooperation in working very well help to understand each other create unity and unity causing kindness to work. Administrators will be able to win teachers' hearts, and be the one your teacher believes in honor and loyalty. Teachers will work willingly, and it will make school administration run smoothly and successfully (Green, Jack Coulson, 2005: 3913) [3].

In this regard, performing school administration duties must be an empathetic person. It is necessary to train oneself to qualify according to the virtues of Buddhist principles which are principles related to the governance and care of people that should be there as an anchor for the mind and direct the behavior. Therefore, it is known to live a transparent life pure and behave by nature both myself and others to make the school administration most beneficial. This is consistent with the research of Worapas Prasomsuk (2006: 199) [4] that has been researched on "Principles of education administration according to Buddhadhamma", the results of which were found that 7 principles are consistent with the principles of education administration in self-dominance, occupation of workers, namely Kanlayan Mittata, Yonisamanasikarn, Dhamhaigam II, Sujarit III, Garasadham IV, Sangahavutthu IV, and Sapphurisadham VII, which the researcher has applied the results of this research to continue this research in order to make the school management successful and achieve objective. Goals were set Efficiently by focusing on the interpersonal relationship of school administrators that is considered an important factor that allows the operation of various aspects to be smooth, created cooperation with each other in the work. Therefore, school administrators should build human relations with teachers relevant personnel for school success school administration, therefore, it is necessary to have guidelines on the principles of administration according to the manual for the administration of juristic institutions. This has the concept of school administration. The school administrators need to have principles in conjunction with school administration to make the work related to the organization of the administration of other service organizations to achieve the quality standards and goals set.

Therefore, the researcher is interested in researching the integration of human relations with Buddhist principles for elementary school administrators. The obtained research results can be used for determination and integration. Appropriate application of school administration as well as being able to utilize the research results as a guideline for consideration, improvement or integration school administration that can be integrated with Buddhist principles for further efficiency.

\section{Research Objectives}

The purpose of the research article was to propose the enhancement of human relation integrating Buddhist principles for administrators of primary schools in Thailand.

\section{Research Method}

This study Researchers used a survey research model, along with In-depth Interview and Focus Group Discussion, which was a mixed methods research between quantitative research and qualitative research by analyzing data from documents, textbooks, statistical data, research reports of various departments, academic articles, dissertation, as well as relevant research work, and a formal in-depth interview by using the interview questionnaire created by the researcher to study the opinions of the school administrators who are the target groups as a case study, there were 390 sets of questionnaires distributing to the administrators and elementary school teachers of Bangkok Metropolitan Administration, interviews with key informants are 20 school administrators and questionnaires for focus group discussion with 11 experts. The researcher collected the data and analyzed the data as follows: 1) qualitative data was analyzed by using content analysis, 2) quantitative data were analyzed by using percentage statistics, frequency, mean, standard deviation. Data from interview and focus group discussion were analyzed by using content analysis and summarizing results research objectives.

\section{Research Results}

The results of studies on human relations and Buddhist principles for school administrators, and opinions towards the integration of human relations with Buddhist principles for elementary school administrators. The 3 aspects of Bangkok Metropolitan Administration consisted of 1) personal characteristics, 2) understanding of others, and 3) 
aspects of working with others, overall at a high level while each aspect was at a high level in all aspects.

The results of the study on the integration of human relations with Buddhist principles for elementary school administrators integrating the principles of human relations with the principles of Buddhism; For elementary school administrators Bangkok Metropolitan Administration consists of 1) principles of human relations for school administrators. It is the expression level of school administrators. In communicating and coordinating both formal and informal between school administrators and teachers, students and the community in order to cooperate in working to achieve the objectives, divided into 3 areas: (1) personal characteristics, (2) understanding of others, (3) working with others. 2) Buddhist principles used in school administration. It is a Buddhist doctrine that is integrated with the principles of human relations, consisting of 7 things: (1) Kalayanamitta, (2) Yonisamanasikarn, (3) Dhamhaigam II, (4) Sujarit 3 (5) Garasadham IV, (6) Sangkhahavatdham IV, (7) Sapphurisadham VII.

The results of the presentation of guidelines on the integration of human relations with Buddhist principles for elementary school administrators, presentation of the integration of human relations with Buddhist principles for elementary school students under the Bangkok Metropolitan Administration (3 Flowers Model) must have 3 important focus points: 1) Human relations for school administrators. It is the expression level of school administrators. In communicating and coordinating both formal and informal Between school administrators and teachers, students and the community in order to cooperate in working to achieve the objectives, divided into 3 areas: (1) personal characteristics, (2) understanding of others, (3) working with others, 2) Buddhist principles used in school administration, it is a Buddhist doctrine that is integrated with the principles of human relations, consisting of 7 things: (1) Kalayanamitta (2) Yonisamanasikarn (3) Dharma makes beauty 2 (4) Sujarit III, (5) Gharavasa Dham IV, (6) Sangkhahavatthudham IV, (7) Sapphurisadham VII. 3) Principles of school administration, It is the operation in working in four areas of the school, including (1) academic administration, (2) budget management, (3) personnel management, and (4) general administration.

\section{Discussions}

Integrating the principles of human relations with the principles of Buddhism for elementary school administrators. The 3 aspects of Bangkok Metropolitan Administration consisted of 1) personal characteristics, 2) understanding of others, and 3) aspects of working with others, in overall at a high level while each aspect was at a high level in all areas. Integration of human relations with Buddhist principles of school administrators under Bangkok Metropolitan Administration have good interpersonal relationships. It is highly effective, which is consistent with the research of Eaamon Chonlaworn (2012) [5]. The results showed that there are two types of knowledge: tacit knowledge and explicit knowledge in the knowledge management process trying to bring the knowledge deeply ingrained in people through the exchange of knowledge interact together although there are many different methods of knowledge management. However, the researcher sees that the knowledge management process is often limited by many factors, which may cause the knowledge management process to fail to function fully, while when considering knowledge management in Buddhism, it is seen that there is inheritance. The body of knowledge has been through a long period of 2,600 years, which is very long, demonstrating the process of knowledge management in Buddhism is a very efficient process, thus able to maintain the whole body of knowledge. Guideline and the righteousness by the researcher that there are four categories of outstanding principles in Buddhism which can lead to the succession process. In building a society to understand each other, the creation of a learning process from within with the principles of conscience; the process of organizing the body, poetry, dharma and discipline into categories, easy to remember and implement; and the monastic society building process including discipline and the method of practice on the formation of monastic groups from knowledge in the area of knowledge management and the body of knowledge in Buddhism. In the past, the researcher has applied all four categories of Buddhism to create an integrated Buddhist knowledge management model. The researcher started from applying the knowledge spiral model of Ikujiro Nonona. The shift (Ikujiro Nonaka), called Seki (SECI), came as the main idea of the practice. It has four elements: (1) socialization (socialization), (2) extraction of knowledge from the person (Externalization), (3) knowledge integration (Combination), (4) to combine knowledge in oneself (Internalization) is the dynamic that is rotated in a spiral (spiral) creating endless new knowledge, then bring the above 4 categories of Buddhism to strengthen the driving force to drive which was proposed as a new model. After that the aforementioned model was used to examine the knowledge by experts with a focus group process concluding that an integrated Buddhist knowledge management model was available to be used in the general organization. It is also consistent with Magnuson research (2001) [6] researching the characteristics of successful school managers. The characteristics of school administrators were classified into two characteristics, namely occupational characteristics, (Professional Characteristics) and personal characteristics (Personal Characteristics) have summarized the professional characteristics that should have the ability to communicate with and understand others well, pay attention and listen to the opinions of others. For the personal features of that, it should consist of you integrating the principles of human relations with the principles of Buddhism. For elementary school administrators Bangkok Metropolitan Administration consisted of 1) principles of human relations for school administrators. It is the expression level of school administrators. In communicating and coordinating both formal and informal between school administrators and teachers, students and the community in order to cooperate in working to achieve the objectives, divided into 3 areas: (1) personal characteristics, (2) understanding of others, (3) working with people others and 2) Buddhist principles used in school administration. It is a Buddhist doctrine that is integrated with the principles of human relations, consisting of 7 things: (1) Kalayanamitta (2) Yonisamanasikarn (3) Dharma makes beauty 2 (4) Sujarit III, (5) Gharavasa Dham IV (6) Sangkhahavatdham IV, (7) Sapphurisadham VII, 
which is consistent with the research results of Pattanasorn Kiatthitikun (2014) [7], on the model of integrating Buddhism principles in the development of efficiency Operation of the municipal authorities, the results of the research showed that 1) the performance of the municipal officials Bangkok Organization Organized according to the policy of Bangkok to facilitate the general public using sidewalks. It should let everyone follow the rules reduce indirect problems Bangkok policies are clear in the use of public spaces and safety care to strengthen the police by inspecting the area maintaining safety in service and facilitation nature which had to risk a disaster in inspecting the area both during the day and at night. For traffic supervision and traffic facilitation, the municipal officer is an assistant traffic officer, it does not a traffic officer. Therefore, in performing work, special care must be taken. This is because there is no law to support the performance of their duties and should provide the necessary tools to perform their work tourism administration. In order to facilitate tourists and represent public relations, along with the supervision of safety and organization at the same time, other special missions are a reinforcement and help coordinate with officers of other relevant departments such as police officers, firefighters, rescuers, electricity and water utilities. 2) Buddhist principles were integrated into their operations at a high level. Considered by in descending average order, we found that integrating the precepts to organize followed by integrating the principles of safety integrating the principles of peace in tourism administration. The integration of the existential principles in the care of other special and least missions is the integration of the compassionate principles. 3) Presenting the model of integrating Buddhism principles in the development of the efficiency of traffic performance of the municipal officer Bangkok, the "Big.CAMP Model", which corresponds to Love Bangkok policy to create Bangkok as a city that is livable and worth visiting. Precepts $\mathrm{B}=$ Behavior refers to the control of behavior, both physical, speech and mind in the work to comply with the city organizing policy allowing everyone to use the public space together safely through their own internal controls (Internal), such as encouraging the municipal officers to have courses to join the training morality, together with the MCU, and in acting with the general public (General), $\mathrm{C}=\mathrm{Control}$ means tolerating difficulties in performing work, tolerating the rigors of the working environment, and tolerating the incomprehensibility of traders and people, $\mathrm{A}=$ Action refers to acts that express help, goodwill, generosity, such as helping to organize traffic in the morning - evening, taking into account the safety of the people, complimenting words, $\mathrm{M}=$ Morality means speaking polite, humble, sincere, suggesting something useful, build human relations with the audience with a smile, good-natured, able to publicize, recommend routes and important places to tourists and people who pass by, to assist tourists with willingly like relatives knowledge of local culture and attitude, $\mathrm{P}=$ Public Mind refers to volunteerism, enthusiasm for performing duties, strive to help by organizing a duty check out at regular intervals in order to monitor the safety of the people and also consistent with the research of Vasita Kerdpholprasopsak (2014) [8] researched on "Buddhist Integrated Management Model of Local Administrative
Organization". The findings were as follows: 1) the overall management of the local government organization was at a high level, but there were still various problems in the administration, not according to regulations, budget allocation problem, does not meet the needs of the community, and the problem of inadequate and inadequate public service. The construction problem of public utilities does not meet the needs of the community. The personnel management lacked knowledge and competence in each area. 2) The study of theoretical concepts and Buddhist principles related to the integrated Buddhist management, it was found that the use of the principle of Iddhipada IV was used as the main guideline for integrated administration and there are principles of Brahma Vihan IV, Sangkhahavatthu IV, Dithitthammikatthaprayoy IV as components. 3) The Buddhist model of integrated administration of local government organization found that the local administrative organization. There are 3 integrated building techniques (3C): co-ordination, co-operation, and consistency in the administration of local government organizations at 3 levels: Provincial administrative organization, municipality and administrative organization district. There are three aspects of local work: finance, personnel and participation by local work groups.

Presentation of the integration of human relations with Buddhist principles for elementary school students under Bangkok (3 Flowers Model) must have 3 important focus points: 1) Human relations for school administrators. It is the expression level of school administrators. In communicating and coordinating both formal and informal between school administrators and teachers, students and the community in order to cooperate in working to achieve the objectives, divided into 3 areas: (1) personal characteristics, (2) understanding of others, (3) working with people others, 2) Buddhist principles used in school administration. It is a Buddhist doctrine that is integrated with the principles of human relations. 3) Principles of school administration, it is the operation in working in four areas of the school including (1) academic administration, (2) budget management, (3) personnel management, and (4) general administration.

This is consistent with the research results of Pramote Chanboonkaew (2014) [9], on "Buddhist Integration to Promote the Strengthening Strategy in the administration of the Royal Thai Police ", the research found that 1) the concept, theory, strategy, personnel development and Buddhist principles for personnel development of the Royal Thai Police found that there was a clear target establish appropriate work plans (Working), selecting resources that are ready, setting plans for assessments or indicators of success as possible, and responsible organization and agency level. Determination of duties (Function) and roles in promoting strategies for strengthening management in all four areas consisted of good governance by adhering to the principles of global virtue is him and her for strengthening the organization as for the stakeholders and the public, service recipients were satisfied with the administration of the Royal Thai Police by leading the threefold. This is the principle that can develop good behavior in police (precepts), who are committed to performing their duties (concentration) and knowledge in solving problems for people (intelligence) for effective management processes 
that it creates a satisfaction in police officers and (a) selfdetermination, full of knowledge and ability to serve the people (persistence), are determined, concentrated, concentrated on the mission assigned to achieve the goals set by the organization (Chitta) and have understanding in performing duties, having knowledge and reflection according to operational procedures (Wimangsa) and police officers have high performance in performing their duties and have applied technology system in management, found that personnel have negligence. The consciousness is aware of the change in technology. They are wise to use technology that is appropriate for themselves in the situation, and aware of their dangers can build immunity for themselves including knowing how to prevent crime that comes with various modern technology. 2) The general condition of the personnel development of the royal Thai Police found that the obstacle of personnel development was that the people were dissatisfied with the police officers' performance. Many aspects of the Royal Thai Police and thus making the administration less efficient because the police have too much workload instructions to take action not appropriate in some areas. There is a patronage system in the organization. The duty audit system is not yet serious. In terms of high performance in performing duties and applying technology systems in management, it was found that the performance of the police officers under the Royal Thai Police. There are still many weaknesses in technology adoption because staff still lack the skills, expertise, knowledge and technology capability. 3) Integrated Buddhism to promote the strategy to strengthen the administration of the Royal Thai Police: 1. The administration based on good governance principles is based on the aim of cultivating an attitude of intolerance to people who practice evil and the creation of a system of suppressing people who do not fear evil increase the maximum penalty for those who behave evil along with praising the good police. 2. People involved and the public service recipients were satisfied with the administration of the Royal Thai Police, stay at self training Developing good communication skills creating an organizational culture and being open to listening to the people. 3. Efficient management processes is in the cultivation of your ideological power that the police bring love career faith efforts, attention and consideration in the performance of duties. 4. To promote police officers to have high performance in performing their duties and to adopt technology systems in management which personnel must have intelligence, consciousness, set in precautionary measures. Turn the crisis into opportunities and be aware of the use of technology in management services.

It is consistent with the research results of Passa Pasatta (2015) [11], on "Integrating Buddhism principles in the management of transparency of the local government organization", it is about conditions, problems and obstacles in the management of the local government organization in terms of transparency. The implementation of the rule of law to create transparency in the administration consists of 3 important issues: 1) Rules, 2) Regulations, 3) Laws on management and performance of duties of executives and personnel. The leadership of participation to create transparency in the administration consists of 3 important issues: 1) co-think 2) co-act 3) co-examine the management and performance of duties of executives and personnel. The implementation of responsibility to create transparency in the administration consists of 3 important issues: 1) self responsibility, 2) local community responsibility, 3) social responsibility. In the administration and performance of duties of executives and personnel 2. In applying the principles of governance and governance to practice in order to create transparency in management, namely 1) the shame of the actions of wrong 2) fear of wrong doing in bringing the principles. The principles of good governance are applied in practice to create transparency in management, namely 1) regular meetings; 2) meeting together in unison, doing things that should be done; 3 ) do not command what is not overthrow what is ordained; 4) Any of you are adults in the community and respect them, saw your words as something to be heard; 5) All the dignitaries to live well without being persecuted; 6) respect the pagoda; 7) Provide protection, protection, righteousness to all Arahants in order to come up with a good direction in the administration and performance of duties of executives and personnel and in applying the principles of Buddhism and good governance to practice in order to create transparency in management. According to Buddhist principles, there are Buddhist principles that are appropriate and comprehensive in management, both at the individual level by applying the principles of world class Dhamma, which is a principle that reminds oneself to think good, perform good, and implement the 7 principles of principle of working together in unity, respect and respect, and when it is integrated with good governance with the rule of law Principle of participation and responsibility to create transparency of the local government organization. 3. Integrating Buddhism principles in the management of transparency of the local government organization by integrating Buddhism principles together with good governance principles, there are 3 main forms of management of the local government organization, including the form of integrating Buddhism principles for transparency, in the administration of local government organizations in the area of law participation, in responsibility a model of integrating Buddhism principles for transparency in the services of the local government organization in the area of law of law in the field of participation, in the responsibility and the integrated model of Buddhism for transparency in supporting the local government organization in the area of law of law, in the field of participation in responsibility by implementing a model of integrating Buddhism and good governance in the administration, service and support work for transparency of the local government organization to provide complete integration and it is appropriate to apply in the performance of duties of executives and personnel for sustainable development.

\section{Recommendations}

\section{A. Recommendations for practice}

Research results on integrating the principles of human relations with the Buddhist principles of school administrators which from the study results. The researcher has the following recommendations. 
1. Personal characteristics school administrators should focus on self-control that is a model in terms of economy and there is a personality to be strengthened to have a sense of humor on appropriate occasions.

2. Understanding of others school administrators should focus on strengthening teachers' morale. For the success of the work and pay attention to follow up and inquire about operational problems and to take care of the happiness of teachers.

3. Collaboration with others School administrators should be interested in giving advice and thinking in solving teacher performance problems. There is a clear written instruction for the teacher performance, convey meaning that can be put into action and there is a systematic planning, monitoring, evaluation, and performance report.

\section{B. Recommendations for further research}

If there will be further research on the application of the interpersonal principle of school administrators. The researcher would like to suggest conducting research in the following way:

1. Should study the factors affecting the human relations of the executives in elementary school in educational areas.

2. Should be studied in a research that narrows the scope of the research area, and should be defined as a study area only.

3. Should study other factors that affect the principles of human relations with the principles of Buddhism such as activity management educational innovation.

4. Should study the application of other Buddhist principles, such as the Iddhipada IV, the Brahma Vihara IV, in particular areas that can be applied to the human relations of the school administrators.

\section{Conclusion}

Principle of interpersonal relations for elementary school administrators, the 3 aspects of Bangkok Metropolitan Administration consisted of 1) personal characteristics, 2) understanding of others, and 3) the overall collaboration with others at a high level, while each aspect was at a high level in all aspects. Buddhist principles for elementary school administrators Bangkok Metropolitan Administration consists of 1) principles of human relations for school administrators. It is the expression level of school administrators in communicating and coordinating both formal and informal between school administrators and teachers, students and the community in order to cooperate in working to achieve the objectives, divided into 3 areas: (1) personal characteristics, (2) understanding of others, (3) working with others. 2) Buddhist principles used in school administration, it is a Buddhist doctrine integrated with the principles of human relations, consisting of 7 things: (1) Kalayanamitta (2) Yonisamanasikarn (3) Dharma makes beauty 2 (4) Sujarit III, (5) Gharavasa Dham IV (6) Sangkhahavatdham IV, (7) Sapphurisadham VII. For an approach to integrating human relations with Buddhist principles for elementary school administrators under the Bangkok Metropolitan Administration (3 Flowers Model), there must be 3 important focus points which are 1) Human relations principles for school administrators. It is the expression level of school administrators in communicating and coordinating both formal and informal between school administrators and teachers, students and the community in order to cooperate in working to achieve the objectives, divided into 3 areas: (1) personal characteristics, (2) understanding of others, (3) working with others. 2) Buddhist principles used in school administration. It is a Buddhist doctrine that is integrated with the principles of human relations. 3) Principles of school administration, it is the operation in working in all four areas of the school: (1) Academic Administration, (2) Budget Management, (3) Human Resource Management, (4) General Administration. From this research (Rainbow Dhamma Model) can integrate human relations with Buddhist principles for elementary school administrators under Bangkok Metropolitan Administration, it is divided into 3 areas as follows: personal characteristics able to integrate with Buddhism principles in 2 topics: Sujarit III and Sapphurisatdham VII in understanding of others. It can be integrated with Buddhist principles in 3 topics: Kalayanamitta, Yonisamanasikarn, and Dharmahaingam II able to integrate with the principles of Buddhism in 2 topics, Gharavasa Dham IV and Sangkhahavatthu IV.

\section{References}

[1] V. Chatakan, Management techniques for professional education administrators. 2nd edition, Bangkok: Chulalongkorn University, 2009.

[2] R. Chongwisan, Human Relations: Human Behavior in Organization. 2nd edition, Bangkok: Kettraat University Press, 2008.

[3] J. C. Green, The Effectiveness of Board of Directors Nonprofit Organization Serving Developmentally Disabled Adult. Dissertation Abstracts International, 55 (12), June 2005.

[4] W. Prasomsuk, "Principles of educational administration according to the Buddhism" Doctor of Dissertation of Doctoral Studies (Educational Administration Branch). Graduate School: Naresuan University, 2006.

[5] E. Chonlaworn, "Knowledge Management through Integration". Doctor of Philosophy of Buddhism (Branch of Buddhism), Graduate school

Mahachulalongkornrajavidyalaya University, 2012.

[6] W. G. Magnuson, The Characteristics of Successful School Business Manager, 
Doctoral Dissertation, University of Southern California, Los Angeles Inc, 2001.

[7] P. Kiatthitikun. "The model of integrating Buddhism principles in the development of performance of the municipality officials Bangkok", Doctor of Philosophy of Buddhism (Department of Public Administration), Graduate school Mahachulalong University Karnarat Wittayalai, 2014.

[8] V. K. Prasaksak, "An integrated Buddhist management model of local administrative organizations", Ph.D. (Department of Public Administration), Graduate school Mahachulalongkornrajavidyalaya University, 2014.

[9] P. Chanboonkaew, "Buddhist Integration to Promote Strategic Strengthening in the Administration of the Royal Thai Police", Doctor of Philosophy of Buddhism (Department of Public Administration), Graduate school Mahachulalongkornrajavidyalaya University, 2014.

[10] Mahachulalongkornrajavidyalaya University, Thai version of the Tipitaka Chulalongkornrajavidyalaya version, Bangkok:

Mahachulalongkornrajavidyalaya Printing House, 1996.

[11] P. Passatta, "Integrating Buddhism principles in the management of corporate transparency. Local administration Doctor of Philosophy of Buddhism (Department of Public Theology), Graduate School Mahachulalongkornrajavidyalaya University, 2015. 